\title{
HEMA in the map of science
}

\author{
Mátyás Miskolczi Ph.D., Ars Ensis
}

\begin{abstract}
This article aims to place HEMA on the map of science. To be able to start this work I have to find an appropriate definition on science and on discipline (field of science). After describing main characters of a discipline I investigate HEMA if it shows this characteristic or can be recognised as an interdisciplinary field. The second question I focus on is the place of this field between disciplines and interdisciplinary topics. For this investigation $I$ review methods of bibliometrics and scientometrics and choose a fitting method to be able to get an answer. I also choose a relevant sample of publications the chosen method can be performed on. After mapping HEMA and having result of the chosen method I try to give a picture on the development of in-field usage of HEMA-related works (how often relevant articles are cited by other HEMA-related articles).
\end{abstract}

\section{INTRODUCTION}

This article aims to give an approximate determination on HEMA's place between fields of science, where science is mainly considered as a synthetic expression for natural sciences (often referred to simply as "science") and social sciences (often referred to simply as "scholarship"). Therefore the expression "map of science" incorporates both big parts and it is referred to as natural and social sciences as well. Science as expression in this paper is used with its wider meaning including both areas. Considering that this paper mainly focuses on fields of social sciences. Papers dealing with social topics often have a local character which makes these disciplines heterogeneous in contrast with natural sciences.

\section{AIM OF THE ARTICLE}

For there were earlier no defined place for academic publications related to this topic this research will be performed on several selected articles, where references and bibliography will be inspected and categorized by fields of science. I hope to be able to determinate weight points of different related fields among inspected references. The sample of articles is not representative - there is no specification how a representative sample could be selected - therefore my results can only give a rough guess on weights of related fields. I also aim to find an appropriate definition on science and on "field of science" to be able to decide if HEMA could be identified as a separate field of science. For I assume to find HEMA somewhere between History and Sport sciences, I investigate definitions of interdisciplinary fields.

Inspecting resources dealing with this topic I venture upon to map the relationship of these interdisciplinary fields to be able to locate HEMA on a map of science. This result can be useful for researchers to be able to find relevant literal resources easier, define relevant 
models for researching HEMA and identify institutes and non-HEMA researchers who can provide methodological and scientific help for HEMA-researchers' work.

\section{HYPOTHESIS}

1. HEMA can be identified as an interdisciplinary field of science.

2. Main sources of HEMA publications are belonging to different fields of history. As another main kind of sources we can identify other publications on HEMA topics.

3. The number of HEMA-related sources per publication has grown in the last 20 years. (I assume that HEMA-related practical and theoretical research activities have been reinforced by the spread of internet.)

\section{METHODOLOGY AND APPROACH}

Martial arts are often recognised as a group of sport activities. Some of them have an ancient, less a new origin. Sport is considered as an independent field of science, where martial arts have a dedicated place. Historical character assumes the strong relevance of history as a field of science, where more parts of this field can be considered as relevant. Other fields of science can be in scope while researching HEMA. Considering cold weapons described in original sources physics can have a strong relevance too. Injuries and other effects caused by using weapons and techniques described in manuscripts explain the relevance of medical sciences (anatomy in the first line).- More fields of science can be considered as tangential relevant, considering for example biomechanics, economical pertinence of wars and campaigns or cultural, anthropological questions regarding to conquering the new world and spreading HEMA over the sea.

To be able to determinate if HEMA was an interdisciplinary but separate field of science I have to have find an appropriate definition on science and on "field of science". For this purpose I collect definitions from different significant institutes whose scientific activity counts to world's leader category. Based upon these definitions a characteristic of a separate field should be determined which helps to determinate whether HEMA could be a separate field.

As a basis of positioning HEMA between different fields of science I investigate bibliography, resources and citations of different articles and publications on HEMA. Weight and significance of related fields will be determined by selected methods. For mapping different fields and branches of science and a list of methods are described and used by scientometrics, which is also a considered as a field of science.

Selected articles will be put in historical order which makes possible to investigate the relationship of HEMA-related sources listed in their bibliography

\section{WHAT IS SCIENCE}

- Webster: a department of systematized knowledge as an object of study (http:// www.merriam-webster.com/dictionary/science) 
- Oxford: the intellectual and practical activity encompassing the systematic study of the structure and behaviour of the physical and natural world through observation and experiment (bttp:/ / oxforddictionaries.com/definition/english/science)

- The Science Council: "Science is the pursuit of knowledge and understanding of the natural and social world following a systematic methodology based on evidence." (bttp://www.guardian.co.uk/science/blog/2009/mar/03/science-definitioncouncil-francis-bacon)

Based on the definitions above we can say that different approaches on science's meaning have two main points in common. One of these is the systematic character and as a second that it is based on facts (evidence, observation, deductive approach and feedback). Systematic character is underpinned by methodology which also corresponds with the point of facts and evidence: in every field of science proven methodology is the way to inspect facts and execute examinations which finally lead to accepted evidences that can be a pillar of thesis. On the primer line we need facts proven by accepted methodology. There is also a second line where works refer to thesis of the primer ones.

\section{WHAT IS A DISCIPLINE}

As having a rough imagination of the meaning of "science" we should have a look on the definition of "field" or "discipline" of science, which is essential for defining what "interdisciplinary" means. Scientometrics describes methods for science mapping in different approaches, e.g. geographical spreading of a discipline, but also ones for describing relationship between disciplines based upon publication's references (Abercrombile et.al. 2012). As data source of references SCI ${ }^{1}$ is the most common one to use. ISI ${ }^{2}$ subject categories often also give the structure of scientometric maps (e.g.: bttp:// www.leydesdorff.net/map06/). Considering that ISI is mostly dealing with natural sciences and does not go in details of most social sciences (see: bttp:// www 3.isi.edu) social sciences (e.g.: disciplines of history) are hardly displayed on most maps of science.

As a general approach several authors specify characteristics which can be used to identify a discipline. Bridges emphases the significance of research and enquiry for answering specific questions (Bridges 2004:4). According to Burr (1954) methods and own concepts are also important specialities of a separate discipline. Taillon describes a fourstages development process how the examination of a new academic phenomena will be transferred to a discipline. His stages are based on:

1. new subject of matter

2. appropriate methods

3. specific knowledge underpinned by original research publications

4. new ways to present scientific information (Taillon 2009:11-12)

\footnotetext{
1 Science Citation Index

2 Institute of Scientific Information
} 
Stichweh (2001:13728-13729) also emphasises the importance of scientific publications, but also puts a community of authors, the presence of a scientific production process $(\sim$ methodology $)$ and the search for novelties in focus.

Krishnan (2009) has merged views of several authors discussing the question of defining "discipline" started from the etymological origin of the word and including common use of its meaning. He identifies six factors is his work and states that the presence of these factors are likely to determinate a standalone discipline. These are:

1. A particular object of research ,

2. Accumulated specialist knowledge,

3. Theories and concepts,

4. Specific terminologies or a specific technical language,

5. Specific research methods,

6. Institutional manifestation (universities or colleges, respective academic departments and professional associations) Krishnan (2009:9)

After that Krishnan smoothes these strong statement by saying that not all disciplines show all of these six characters, but the more of these a field has the more likely it will be recognised as a separated discipline of science (Krishnan 2009:10).

Upon authors' works mentioned above we find that most of them agree in following factors to contribute to delimit a discipline:

1. Subject of matter

2. Specific knowledge

3. Specific theories and methods

4. Specific terminology

5. Own publications

If we accept the approach suggested by Krishnan we can say that the strength of characteristic described above determines the strength of a standalone discipline. The strength of this characteristic can be imagined as a fuzzy membership factor of being a discipline where its complementary set is being interdisciplinary field of science.

\section{AN ATTEMPT TO DETERMINATE IF HEMA WAS A DISCIPLINE}

Here I try to apply this model on HEMA based on my opinion which can be a matter of discussion. I emphasise that only my own view is included here and it needs a research involving a wide range of specialists dealing with HEMA topics to gain an objective picture or other methods of research could be applied which I did not research now because the time limitation I face during the preparation of my work.

1. Subject of matter: on one hand it can be exactly determined that cold weapon usage approximately in the middle age and the first half of the new age can be this matter, including written material, methods and correspondings. On the other hand there are a 
plenty of research fields which do not aim to deal with HEMA exactly but produce results which can be used effectively in HEMA research projects, just like different fields of history, philology, biomechanics and linguistic.

2. Specific knowledge: I can identify fencing / weapon usage methods described in original manuscripts as a specific kind of knowledge, which is not assumed to be a core field of history science or sport science. Surely other sets of knowledge could be identified but "specific knowledge" is also not exactly defined.

3. Specific theories and methods: if I interpret this aspect as theories and methods of scientific research I'm not sure that a well paled (tested, documented and widely recognised) set of methods can be identified. It can be a field of further development.

4. Specific terminology: Terminology gained from original manuscripts surely can be recognised as specific terminology of HEMA. But if this point is interpreted as terminology of scientific research and methodology it can be only developed by developing scientific theories and methods of HEMA (see previous point).

5. Own publications: analysing relevant sources of HEMA topics I have realised that only few of them can be identified as scientific/scholarly papers (see analysis data below).

Summarising these five points I would say that they describe a kind of development process, where development starts by identifying subject of matter and previous points are priming next ones. As I have summarised my opinion how far HEMA is developed regarding these points in my opinion it shows that subject of matter and specific knowledge could be regarded as being specific to HEMA, while further points are on their way but far not developed enough to prime the identification of HEMA as a discipline. For this reason I identify HEMA as an interdisciplinary field which can be developed to a standalone discipline by intensive and persistent scientific/scholarly activity.

\section{METHODOLOGY OF MAPPING SCIENTIFIC DISCIPLINES}

While bibliometric mapping is mainly based upon the analysis of publications' bibliography (e.g.: Abramo et. al. 2012, Della Mea 2011 and Palmer et.al. 2005), where distribution analysis (assessing counts and percentages) plays a determining role, scientometrics uses another (similar) vary of methods to determinate relationship between disciplines. Among these we can find methods of full text search which uses a list if relevant expressions which indicate relevant disciplines, relations between analysed publications based on co-words and co-citations, or prognostic modelling for deeper understanding the future ways of development of a specific discipline (Ivancheva 2001 and Ivancheva 2008). During my research on HEMA-related publications I did not find any authentic list of relevant keywords. Regarding actual time limits of preparation of this article I do not perform a systematic research on all possible sources of such keyword list but I presume that a comprehensive and authentic source of HEMArelated specific keywords is not available. Further theses based on this supposition can 
be queried. Based upon the set of available data, tools and methods and regarding time frames I'm going to inspect a set of relevant publications by bibliometric methods.

\section{CHOSEN METHOD OF BIBLIOMETRICS}

Analysing articles referred to in previous paragraph I will analyse relevant publications using simple statistical methods assessing counts and percentage of referred sources. An ad-hoc chosen, but relevant sample of publications will be selected, where relevance is based on its topics (indicated in titles) and the place/organisation of publication.

A highly relevant topic of this investigation is discipline-based categorisation of cited sources highlighted in inspected publications' bibliographies. Counts, percentage, distribution and count-based weights are recognised as main indicators. Average number of cited sources, and number of disciplines listed in each publication also will be calculated.

Affected disciplines - weighted by the number of references - will be listed as a result, which is a basis for testing Hypothesis 2 .

\section{RELEVANT SOURCES}

The relevance of publications is determined by their topics and publisher organisation. During this research I have processed only written publications. Publishers are Journal

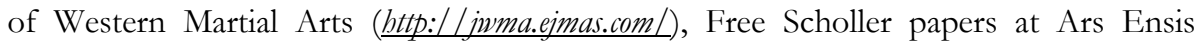
(www.arsensis.hu), Acta Periodica Duellatorum and HEMAC (hemac.org). I have also made search by relevant keywords on SOLO (Search Oxford Libraries Online, bttp://solo.bodleian.ox.ac.uk) in different libraries but there were no relevant matching articles on keywords like "european martial arts", "sword fencing" and similar trials (the best matching paper was the book of Alfred Hutton, but no scholarly articles). This result has underpinned my assumption that there are not many relevant scholarly publications to be found. I also agree that it was not a comprehensive search of relevant publications but it can be regarded as a signal.

The sample I have chosen for analysis was selected from JWMA, Ars Ensis, Acta Periodica Duellatorum 2013 (under publication process when this article was written) HEMAC, Feder (Pl) and Ochs. I have selected all publications from these publishers that had a structured bibliography, a total of 42 publications. The chosen 42 papers have together 700 sources in their bibliographies. More articles were available on most of the chosen sites which did not include a bibliography, lot of them not even any kind of sources or citations. Overall I have found that a lot of interesting articles are published, but the approach and quality is not homogeneous: some articles which do not have any references also include valuable ideas. Others keep a classical structure and are based on referred sources. A small part (under 10\%) show scientific character (hypothesis, methodology, research, conclusion, authentic sources). This fact has also enforced my opinion that the scholarly character of HEMA-related publications should be strengthened. 


\section{KEY FINDINGS OF THE RESEARCH}

Though referring mainly to scientific or scholarly sources is still not an expectation, but articles which use such kind of resources show more scientific character than others, which do not use them. Scientific or scholarly character was supposed if publishing organisation was a scientific one (e.g.: a university, a scientific journal or a research institute). Altogether $23 \%$ of resources were of this kind.

The 24 papers of the sample refer to 24 different fields of science. I have sorted them based on the proportion of references in the total of 700 . The top five most referred fields give nearly $80 \%$ of them. These fields are shown in Table 1.

\begin{tabular}{|l|l|l|l|l|}
\hline$\#$ & Field & Count & $\%$ & Cumulated \% \\
\hline 1 & Original & 206 & $29,43 \%$ & $29,43 \%$ \\
\hline 2 & History & 201 & $28,71 \%$ & $58,14 \%$ \\
\hline 3 & HEMA & 96 & $13,71 \%$ & $71,86 \%$ \\
\hline 4 & Military & 26 & $3,71 \%$ & $75,57 \%$ \\
\hline 5 & Sport & 25 & $3,57 \%$ & $79,14 \%$ \\
\hline
\end{tabular}

Table 1: The top 5 most referred fields of the research sample

(source: own research)

As a speciality of HEMA-related publications I can identify the high percentage of referred original sources (meant: manuscripts, codices, original fight books). The significance of history is also without doubt. On the third place we can find HEMA which I would highlight because of the significance of internal references: researches and articles use the results of other researchers of the same field. It points to the fact that a community of professionals and/or researchers is present or being formed. Its significance is highlighted by Krishnan (2009:9). The high percentage of history and sport supports my original supposition, that HEMA is strongly related to these disciplines.

There are 8 more cited disciplines which have their percentage over $1 \%$ in my sample. These are:

- Philology

- Philosophy

- Psychology

- Medicine

- Cultural History

- Linguistics

- Anatomy

- Archaeology 
I have also analysed the yearly number of HEMA-references in the sample. The chart below shows the yearly distribution of the HEMA-references per publication.

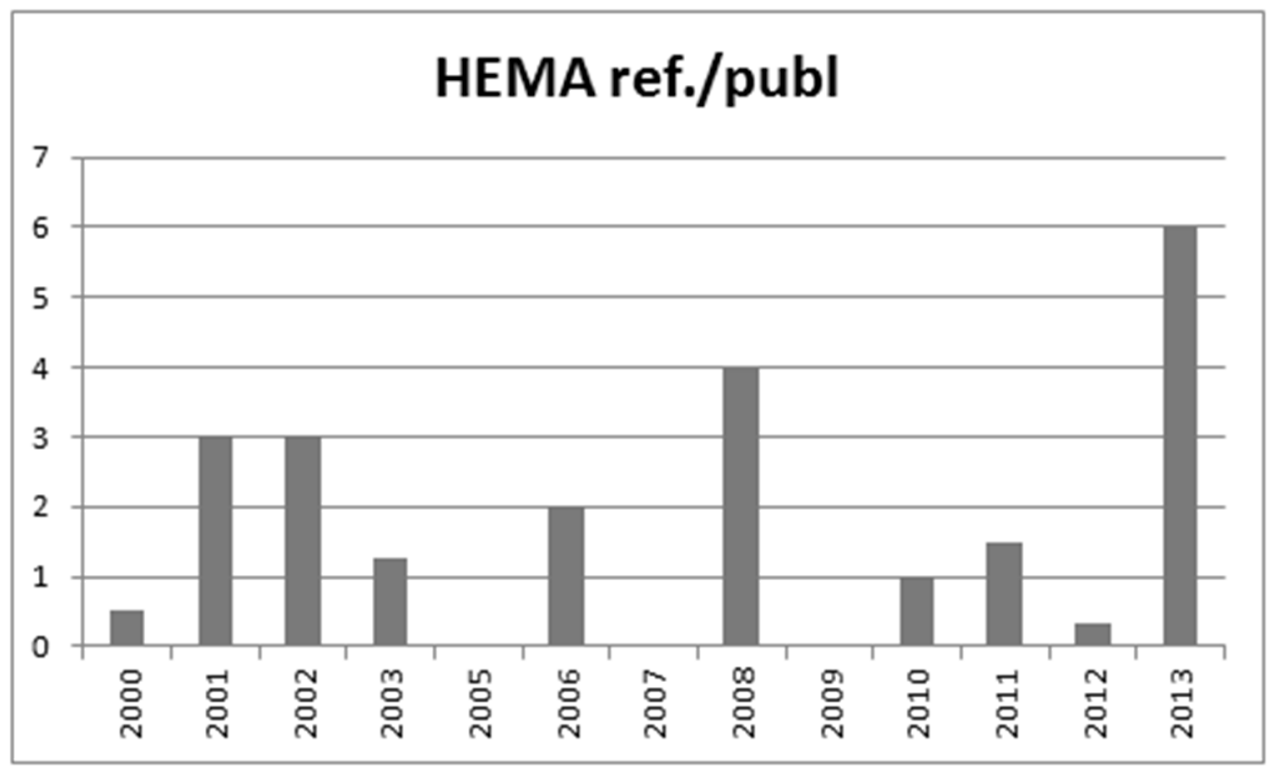

Figure 1.: Yearly distribution of HEMA-related references perpublication in the sample

(source: own research)

The pattern shown by the chart represents no definite trend. The low number of analysed publications can be a reason. I suggest repeating this query on a much bigger sample to get a reliable result.

\section{HYPOTHESIS TESTING}

The first Hypothesis of this article was that HEMA can be identified as an interdisciplinary field of science. I have listed several sources focusing on the topic how a discipline can be identified, what are the key characteristics of a separate/standalone discipline. I have identified five key factors. Based upon the processed relevant works I assume that the presence of these factors can describe how far a field of science can be determined as a discipline. Analysing HEMA based upon these factors I have formulated an opinion that HEMA is still not a discipline but an interdisciplinary field, which can be developed to a discipline by research and scientific/scholarly activity.

As my second hypothesis I have supposed that main sources of HEMA publications belong to history. As another main kind of sources we can identify other publications on HEMA topics. By the analysis of 700 references I have found that history is the second most cited discipline, while HEMA is on the third place. Considering the tight frames of my research the hypothesis can be accepted. 
My third hypothesis was that the number of HEMA-related sources per publication would have grown in the last 20 years. I have assumed that HEMA-related practical and theoretical research activities have been reinforced by the spread of internet. The first problem regarding my hypothesis was that the oldest relevant article I have found in researched sources was from 2000. Surely, in frames of a deeper research - covering more places of publications - earlier articles could be found. The analysis of publications from the last 13 years have shown an indefinite pattern which I consider to be caused by the small size of the sample.

Considering my three hypothesis I have reached marginal results. I have formed a subjective opinion on the first one, I have verified the second one and I was not able to bring a reasonable decision regarding the third one because of the low number of analysed publications.

\section{CONCLUSION}

Historical European Martial Arts is a field of science and scholarly activity which is researched more and more intensively but still cannot be considered as a discipline thus it shows several factors which can later contribute to the development of this field. I have made a small research including 42 publications from the last 13 years containing 700 references in their bibliographies. For its analysis I have made a rough summary on methods of scientometrics and bibliometrics and I have performed a bibliometric analysis on the selected sample. I have mapped HEMA as a field very near to the fields of History and Sport and also highlighted several other relevant disciplines which are also cited by researched articles. Finally, I did not manage to identify any pattern regarding the development of internal references. The size of the sample has created tight frames for my research. The repetition of this research on a significantly bigger sample might bring more reliable results. Among further possible subjects of research I would mention analysis of coincidences of references belonging to different disciplines. Further researches could involve another terms for disciplines such as multidisciplinarity or cross-disciplinarity, and their relation to HEMA. Hopefully my initial work has shown a possible direction of researching HEMA as field of science and its development.

\section{BIBLIOGRAPHY}

\section{1. - Publications}

Abercrombie, R. K. - Udoeyop, A.W. - Schlicher, B.G. (2012): A study of scientometric methods to identify emerging technologies via modeling of milestones. Scientometrics, Volume 91, Issue 2, pp 327-342.

Abramo, G - D'Angelo, C. A. - Di Costa, F (2012): Identifying Interdisciplinarity Through the Disciplinary Classification of Coauthors of Scientific Publications. Wiley Online Library (wileyonlinelibrary.com). DOI: 10.1002/asi.22647, pp. 2206-2222 
Bridges, D (2004): The disciplines and discipline of educational research. Paper for Annual Conference of the British Educational Research Association, Manchester Metropolitan University.

Burr, H. S. (1954): Discipline. The Journal of Higher Education, Vol. 25, No. 6 (Jun., 1954), pp. 319-323

Della Mea, V. (2011): 25 Years of Telepathology research: a Bibliometric analysis. Diagnostics Pathology 2011, 6 (Suppl 1):S26

Ivancheva, L. (2001): The Non-Gaussian Nature of Bibliometric and Scientometric Distributions: A New Approach to Interpretation. Journal of the American Society for Information Science \& Technology; Nov. 2001, Vol. 52 Issue 13, pp. 1100-1105.

Ivancheva, L. (2008): Scientometrics Today: A Methodological Overview. Collnet Journal of Scientometrics and Information Management. Vol.2., No.2. de, 2008. pp. 47-56.

Krishnan, A. (2009): What are Academic Disciplines? Some observations on the Disciplinarity vs. Interdisciplinarity debate. Working Paper, University of Southampton National Centre for Research Methods.

Palmer, A. L. - Sesé, A. - Montaño, J. J. (2005)Tourism and Staistics - Bibliometrics Study 19982002. Annals of Tourism Research, Vol 32. No.1. pp.167-178.2005

Stichweh, R. (2001): Scientific Disciplines, History of. International Encyclopedia of the Social \& Behavioral Sciences. Elsevier Science Ltd.

Taillon, J. (2009): Understanding Tourism as an Academic Community, Study, and/or Discipline. PhD dissertation at Texas A\&M University, 14. May 2009.

\section{2. - Websites' content}

bttp:/ / www.merriam-webster.com/ dictionary/ science (downloaded: 28.12.2012)

bttp:// oxforddictionaries.com/definition/english/science (downloaded: 28.12.2012)

bttp:/ / www.guardian.co.uk/ science/blog/2009/mar/03/science-definition-council-francis-bacon (downloaded:

28.12.2012)

bttp:// www.leydesdorff.net/map06/

bttp://wnw3.isi.edu

http://jwma.ejmas.com/php-bin/jwma content.php?LLM=0\&Tab=articless $M D=$

http://arsensis.hu/index.php?s $=714$

feder.org.pl

http:/ / www.schwertkampf-ochs.de/essays.html 


\section{3. - Articles used for bibliographical research:}

\begin{tabular}{|c|c|c|c|c|}
\hline \# & Author & Title & Journal/Book & Year \\
\hline 1 & |Jaquet, D & $\begin{array}{l}\text { Fighting in the Fightschools late XVth, } \\
\text { early XVIth century }\end{array}$ & $\begin{array}{l}\text { Acta Periodica Duellatorum } \\
\text { (under publishing) }\end{array}$ & 2013 \\
\hline 2 & Talaga, M & $\begin{array}{l}\text { A Kampfschwert from the 15th century - a } \\
\text { reinterpretation of the so called 'Teutonic } \\
\text { estoc' from the Princes Czartoryski } \\
\text { Collection in Cracow, Poland. }\end{array}$ & $\begin{array}{l}\text { Acta Periodica Duellatorum } \\
\text { (under publishing) }\end{array}$ & 2013 \\
\hline 3 & Waldmann, Sz & $\begin{array}{l}\text { Mertein Hündsfelder: Fechtlehre mit dem } \\
\text { Kurzen Schwert, circa } 1491 \mathrm{AD}\end{array}$ & $\begin{array}{l}\text { Acta Periodica Duellatorum } \\
\text { (under publishing) }\end{array}$ & 2013 \\
\hline 4 & Cvet, D.M. & $\begin{array}{l}\text { A Brief Examination of Fiore dei Liberi's } \\
\text { Treatises }\end{array}$ & JWMA & 2008 \\
\hline 5 & Cvet, D.M. & The Measure of a Master Swordsman & JWMA & 2005 \\
\hline 6 & Howe, R & Fiore dei Liberi : Origins and Motivations & JWMA & 2008 \\
\hline 7 & Dupuis, 0 & $\begin{array}{l}\text { A fifteenth-century fencing tournament in } \\
\text { Strasburg }\end{array}$ & $\begin{array}{l}\text { Acta Periodica Duellatorum } \\
\text { (under publishing) }\end{array}$ & 2013 \\
\hline 8 & Bas, $P$ & $\begin{array}{l}\text { The true edge: a comparison between self- } \\
\text { defence fighting from German "fencing- } \\
\text { books" (Fechtbücher) and the reality of } \\
\text { judicial sources (circa } 1400 \text { to 1550). }\end{array}$ & $\begin{array}{l}\text { Acta Periodica Duellatorum } \\
\text { (under publishing) }\end{array}$ & 2013 \\
\hline 9 & Chandler, J & $\begin{array}{l}\text { A brief examination of warfare by } \\
\text { medieval urban militias in Central and } \\
\text { Northern Europe }\end{array}$ & $\begin{array}{l}\text { Acta Periodica Duellatorum } \\
\text { (under publishing) }\end{array}$ & 2013 \\
\hline 10 & Garry, J & $\begin{array}{l}\text { Bayonet Fencing : World War I French } \\
\text { Method }\end{array}$ & $\begin{array}{l}\text { Acta Periodica Duellatorum } \\
\text { (under publishing) }\end{array}$ & 2013 \\
\hline 11 & Törcsvári, A & $\begin{array}{l}\text { Translation memory and computer assisted } \\
\text { translation tool for medieval texts }\end{array}$ & $\begin{array}{l}\text { Acta Periodica Duellatorum } \\
\text { (under publishing) }\end{array}$ & 2013 \\
\hline 12 & Rasmusson, M & $\begin{array}{l}\text { Blossfechten and the Fechtschulen - } \\
\text { German Judicial and Sport Dueling from } \\
\text { the Dark Ages to the Renaissance }\end{array}$ & JWMA & 2003 \\
\hline 13 & Hackney, C & Reflections on audatia as a Martial Virtue & JWMA & 2006 \\
\hline 14 & Hand, S & The Practical Saviolo & JWMA & 2003 \\
\hline 15 & Lovett, $R$ & $\begin{array}{l}\text { Principles of Fiore Dei Liberi's Martial } \\
\text { System }\end{array}$ & JWMA & 2002 \\
\hline 16 & Walczak, B & $\begin{array}{l}\text { The Importance of Studying Historical } \\
\text { Treatises }\end{array}$ & JWMA & 2002 \\
\hline 17 & Docherty, F & A Brief History of the Quarterstaff & JWMA & 2001 \\
\hline 18 & Zabinski, G & $\begin{array}{l}\text { Several Remarks on the Blossfechten } \\
\text { Section of Codex Wallerstein }\end{array}$ & JWMA & 2001 \\
\hline
\end{tabular}




\begin{tabular}{|c|c|c|c|c|}
\hline$\#$ & Author & Title & Journal/Book & Year \\
\hline 19 & Martinez, R & The Demystification of the Spanish School & JWMA & 2001 \\
\hline 20 & Mondschein, $\mathrm{K}$ & Towards a Historiography of Fencing & JWMA & 2001 \\
\hline 21 & Kautz, P & Fiore dei Liberi's 7 Rules of Wrestling & JWMA & 2001 \\
\hline 22 & Hand, S & A Matter of Time & JWMA & 2000 \\
\hline 23 & Roberts, C & About Cornish Wrestling & JWMA & 2000 \\
\hline 24 & Nelville, N.T.H. & $\begin{array}{l}\text { The Incised Effigial Stone at Foveran, } \\
\text { Aberdeenshire }\end{array}$ & JWMA & 2000 \\
\hline 25 & Pfrenger, $\mathrm{K}$ & Early Cornish Wrestling & JWMA & 2000 \\
\hline 26 & Berkes, Z & Fabian von Auerswald birkózókódexe & $A E$ & 2010 \\
\hline 27 & Csepeli, A & $\begin{array}{l}\text { Harci lovak, csatamének a középkori } \\
\text { Nyugat-Európában }\end{array}$ & $A E$ & 2010 \\
\hline 28 & Faragó, P & $\begin{array}{l}\text { A sportolás során szerezhető sérülések } \\
\text { és más kóros hatások ismertetése és } \\
\text { azok ellátása }\end{array}$ & $A E$ & 2010 \\
\hline 29 & Fogl, L & $\begin{array}{l}\text { HARC LÓHÁTON - FIORE DEI LIBERI, } \\
\text { PAULUS KAL ÉS HANS TALHOFFER } \\
\text { KÓDEXE ALAPJÁN }\end{array}$ & $A E$ & 2010 \\
\hline 30 & Majár, J & A LOVAGI ETIKA ADAPTÁLHATÓSÁGA & $A E$ & 2010 \\
\hline 31 & Németh, G & Lovagok, Rendek, Lovagrendek & $A E$ & 2012 \\
\hline 32 & Tóth, B & $\begin{array}{l}\text { AZ 1346-1347-ES ANGOL } \\
\text { CHEVAUCHÉE FRANCIAORSZÁGBAN }\end{array}$ & $A E$ & 2012 \\
\hline 33 & Horváth, K & $\begin{array}{l}\text { A humánbiológia tárgykörének általános } \\
\text { leírása }\end{array}$ & $A E$ & 2010 \\
\hline 34 & Kerese, M & Keresztes hadjáratok & $A E$ & 2009 \\
\hline 35 & Waldmann, Sz & A német érett gótikus vért & $A E$ & 2009 \\
\hline 36 & $\begin{array}{l}\text { Waldmanné, } \\
\text { Cs.M. }\end{array}$ & Edzéstartási útmutató & $A E$ & 2009 \\
\hline 37 & Schunder, L. & Training theory of longsword fencing & HEMAC & 2012 \\
\hline 38 & Richards, C. & Some Aspects of Medieval Dagger & HEMAC & 2003 \\
\hline 39 & Walczak, B & The Importance of Studying Fechtbücher & HEMAC & 2003 \\
\hline 40 & Lorbeer, C. & $\begin{array}{l}\text { Erkennen, Analyse und Korrektur von } \\
\text { Fehlern }\end{array}$ & Ochs & 2007 \\
\hline 41 & Chodkiewicz, J & $\begin{array}{l}\text { Fechtunek na bagnety w Królestwie } \\
\text { Polskim 1815-1830 }\end{array}$ & Feder & 2011 \\
\hline 42 & Wanke, $T$ & Meisterhäue in a different way & Ochs & 2011 \\
\hline
\end{tabular}

